\title{
PERFORMANCE MANAGEMENT - A BASIC INSTRUMENT FOR SUSTAINABLE DEVELOPMENT OF POMICULTURE
}

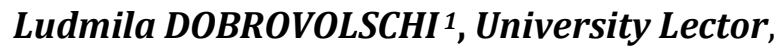 State Agrarian University of Moldova}

Fruit growing has become an area of great interest for economic agents. Recently, it has been more difficult for the businesses to enter the market, which requires differentiation in management activity. In this sense, formulating the role of performance management in terms of consumer behaviour becomes a trampoline for effective management actions. In the scientific literature, it is given a minor attention, as evidenced by the low degree of research in the field of efficient management and of the sustainable development of fruit growing. Under these circumstances, the need to study the performance management as a basic tool in the sustainable development of fruit growing of the Republic of Moldova is more than adequate. Thus, the main objective of this article is the conceptual approach of advanced management - as a basic tool in the sustainable development of fruit growing. The informative basis of the investigation consisted of the consulted bibliographic sources, on the basis of which the author presented his own visions. The main research methods used were: monographic method, analysis, scientific observation, comparison, induction, deduction, explanation and interpretation. The obtained results highlighted: defining the notion of performance management, identifying its characteristics, specific functions and basic levers; value chain determination methodology and the impact of the developed value chain on the process of identifying export markets for Moldovan fruit.

Keywords: management, performance management, performance, sustainable development, horticulture, enterprise, market, efficiency, effectiveness, competitiveness, functions, value chain, investments.

Pomicultura a devenit un domeniu de activitate de mare interes pentru agenții economici. În ultimul timp, întreprinderilor le este mai dificil să abordeze piața, fapt care impune diferențierea activității de management. În acest sens, formularea rolului managementului performant în funcție de comportamentul consumatorilor devine drept trambulină pentru acțiunile eficiente de management. În literatura științifică, managementului performant îi este acordată o atenție minoră, ceea ce este demonstrat de gradul redus al cercetărilor din domeniul managementului performant - dezvoltării durabile a pomiculturii. În aceste condiţii, necesitatea studierii managementului performant, ca instrument de bază în dezvoltarea durabilă a pomiculturii Republicii Moldova, este mai mult decât oportună. Astfel, obiectivul principal al prezentului articol constă în abordarea conceptuală a managementului performant ca instrument de bază în dezvoltarea durabilă a pomiculturii. Baza informativă a investigaţiei sunt sursele bibliografice consultate, conform cărora autorul şi-a expus viziunile proprii. Principalele metode de cercetare utilizate au fost: metoda monografică, analiza, observarea științifică, comparaţia, inducția, deducția, explicarea şi interpretarea. Rezultatele obţinute evidenţiază: definirea noțiunii de management performant, identificarea caracteristicilor, funcţiilor specifice și pârghiilor de bază ale acestuia; metodologia de determinare a lanţului valoric prin prisma costurilor şi impactul lanțului valoric dezvoltat asupra procesului de identificare a piețelor de export pentru fructele moldoveneşti.

Cuvinte-cheie: management, management performant, performanță, dezvoltare durabilă, pomicultură, întreprindere, piaţă, eficienţă, eficacitate, competitivitate, funcții, risc, lanț valoric, investiții.

Плодоводство стало областью большого интереса для экономических агентов, в то же время предприятия испытывают определенные сложнности при выходе на рынок, что требует дифференциации в управленческой деятельности. В этом смысле формулирование роли управления эффективностью с точки зрения поведения потребителей становится трамплином для эффективных управленческих действий. В научной литературе этой проблеме уделяется незначительное внимание, о чем свидетельствует низкая степень исследований в области эффективного управления, устойчивого развития плодоводства. В этих условиях необходимость

1 @ Ludmila DOBROVOLSCHI, liuda.dob@mail.ru

No. $1 / 2019$ 
изучения управления эффективностью как основного инструмента устойчивого развития плодоводства в Республике Молдова являетсяпредставляет особую актуальность. Основной целью данной статьи является концептуальный анализ передового менеджмента как основного инструмента устойчивого развития плодоводства. Информационную основу исследования составили библиографические источники, на основании которых автор представил свои собственные взгляды. Основные методы исследования: монографический метод, анализ, научное наблюдение, сравнение, индукция, дедукция, объяснение и интерпретация. Основныерезультаты исследования: определение понятия управления эффективностью, определение характеристик, конкретных функций и основных рычагов; методология цепочки создания стоимости и её влияния на процесс определения экспортных рынков для молдавских фруктов.

Ключевые слова: управление, управление эффективностью, производительность, устойчивое развитие, садоводство, предприятия, рынок, эффективность, эффективность, конкурентоспособность, функции, риск, цепочка создания стоимости, инвестиции.

DOI: https://doi.org/10.36004/nier.es.2019.1-06

JEL Classification: A10, D22, M11, M21

UDC: 005:634

Introduction. In the conditions of increasing complexity and dynamics of the socio-economic phenomena, management acquires new valences and has a major role in achieving efficiency, in the development and modernization of the economy, for the material and spiritual progress of the individual and society. This means that the major problems faced today and in the foreseeable future by the Moldovan enterprises (the necessity of ensuring and accelerating the economic growth, the economic crisis, the pollution, the reduction of the poverty level in the society, etc.) are likely to be solved only in case the management at the level of the organizations proves to be effective and efficient in capitalizing on the used resources and maximizing the contribution of these organizations to the development of the society as a whole.

Managerial concerns have intensified and amplified with the development of human society, leading to a leadership and organization activity with superior structural and functional characteristics [12, p.14].

In the Republic of Moldova in the last decades the fruit growing branch has been one of the main pillars of the national agriculture, determining to a large extent the efficiency of the agricultural sector as a whole. The fruit growing branch generates a considerable share of income in horticultural production, being at the same time the essential source of income for a great part of the country's population and the core activity of the majority of the 323,000 people employed in agriculture.

The Republic of Moldova is in the immediate neighbourhood with two of the largest markets for fruit products - the European Union and the Commonwealth of Independent States (CIS). Despite this, the potential of this branch is being exploited inefficiently due to the limited absorption capacity of the local market, the reduced competitiveness of the products on the markets, as well as the barriers imposed by the Russian Federation on the import of fruit products.

Under these circumstances, the sustainable development of fruit growing essentially depends on the quality of management at the branch level, which would focus on researching all the possibilities that can be applied to make the most of the trading capacity of these markets and beyond.

The pertinent approach to the issue of high performance management as a basic tool for the sustainable development of the Republic of Moldova implies the increase of the efficiency at branch level, which will increase the competitiveness of the domestic fruit products, having a positive impact on the increase of the sale degree and facilitating the efficient utilization of their potential.

As there exist the opportunities of Moldova's association with the European Union and the changes in the trade regime of key partners, the sustainable and competitive development of the fruit-growing branch based on a high-performance management would be of interest to science and practice.

Data sources and methods used. The scientific research methods applied in the present paper have served to deepen the study and knowledge of the field of performance management in the sustainable development of fruit growing. The main research methods were: monographic method, analysis, synthesis, scientific observation, comparison, induction, deduction, explanation and interpretation, table method. Qualitative and quantitative research has been used to collect primary

No. 1 / 2019 
data about the real state of fruit growing using direct research tools such as focus group, survey, indepth interviews, brainstorming, and discussion.

The primary data collected in the research project "Sustainable development of the horticultural sector in the context of the economic security of the Republic of Moldova", no. 65P, cipher 15.858.06.02A served as the data sources necessary for the fruit value chain formation.

Results of own research. Recently, in the specialty literature a new vision of management has emerged, namely "performance management", which, according to the author, implies an evolutionary-superior phase of management. The author has not identified any definition of performance management, but there are enough approaches to the concept of "performance management," which is a new concept in the human resources management (HRD).

In this context, the author defines the performance management as follows: "performance management represents all the actions undertaken by managers in order to ensure lasting success in the activity of the organizations, based on the application of modern methods, managerial techniques and information technologies, in order to improve the managerial performance and economic performance of the organization".

The main features of the performance management identified by the author (survival, results and effectiveness, productivity, efficiency, practical decision-making, competitiveness) allow us to conclude that these characteristics are interdependent, complementing each other and all of them form the conceptual framework of performance management.

In order to make the management more efficient, managers should apply the general management functions in practice, and these are supplemented, in the author's view, with four other important functions.

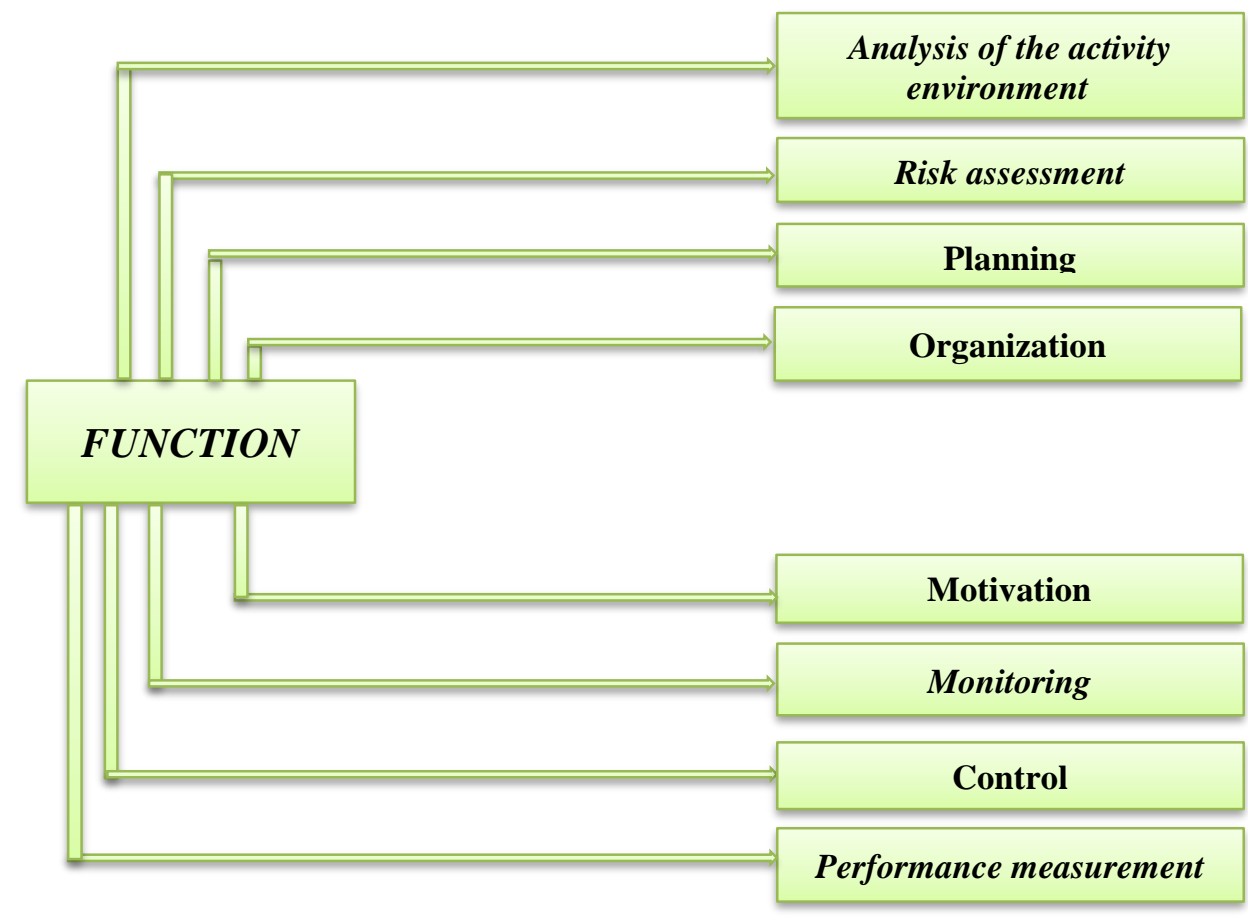

Figure 1. Performance management functions

Source: Systematized and adapted by the author based on the source [79, p.25].

We consider that the analysis of the activity environment is a welcome and necessary function of the performance management. Thanks to this function, the organization could better: determine the future evolution of economic and social phenomena; identify and manage all the opportunities and risks, the strengths and weaknesses, which would help to know competitors and to develop the objectives to be predicted in the near and distant future. Achieving this function with great care will condition the performance of the organization in all its areas of activity. Managers, recognizing and practicing this 
function with great skill, would have much greater chances of success in achieving the goals with higher performances and for a longer period of time.

The function of the possible risk assessment is a necessary function of the performance management that implies risk identification through the activity environment analysis.

According to the author, this function must include the following actions:

- adopting decisions to assess the identified risky situation;

- determining of the expenses necessary for the identified risk assessment and the adoption of the final decision: to accept the risk; to avoid the risk; to transfer the risk;

- determining of the consequences of the identified risk and its severity by activity domains;

- quantification of the consequences (based on quantitative and/or qualitative methods), also taking into account certain limits of variability (size of admissible risk);

- determining the responsibilities and ways to minimize or eliminate the risk;

- applying the necessary measures to eliminate the causes of risk, minimize or liquidate the risk;

- developing a plan of actions and measures to prevent, combat, reduce and avoid risks.

Organization, as a function of the executive management, has a diversity of opinions regarding its definition. One of the definitions belongs to the local scholars Burlacu N., Cojocaru V., who mention that "the organizational function consists in creating the formal structure of the organization, the selection of the necessary staff to carry out the decisions adopted at the planning stage" [13, p.176].

The motivation function involves attracting staff to achieve the organization's goals. Without participation of the labour force, the achievement of the predetermined objectives is practically impossible, and the action of the managers in the application of the motivation function consists in attracting the staff so that the organization could function normally and achieve superior economic performance.

Monitoring, in the author's opinion, is defined as "all activities of surveillance, careful follow-up of activities at any level, at any organizational component in order to know and understand at any time the tendencies of carrying out the activities foreseen in the plans and programs ". Monitoring should be done on a daily basis in the full course of activities and can be done through selective discussions with the personnel involved in the various activities, by recording the results and the problems that have arisen, by observing the planned activities step-by-step.

Control requires permanent and complete verification of how different activities are carried out in relation to fixed programs, highlighting deviations and taking corrective measures [35, p.122]. From this definition and other definitions presented in the literature, we can assume that the exercise of the control function for a performance management must be performed in relation to the activities specific to the fulfilment of the other functions described above.

Performance measurement, in the author's opinion, is a specific performance management function that should focus on identifying, monitoring, and communicating results by using performance indicators. Performance measurement should be more complex in evaluating results, while performance management involves decision-making based on measurement results to achieve the desired performance. Performance indicators are core assessment tools, communicating important issues related to the definition and achievement of the objectives.

We believe that in order to achieve an efficient management and to ensure the long-lasting success of organizations, managers should apply all these functions.

Along with the functions we have determined that the main levers of the performance management that influence sustainable development are as follows:

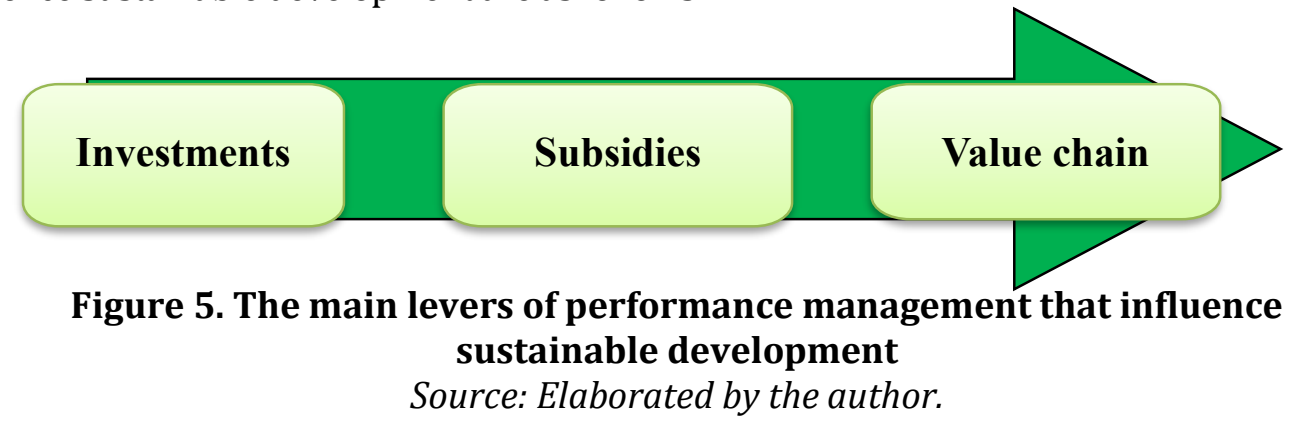

No. $1 / 2019$ 
Investments, as one of the main levers of performance management, contribute to the sustainable development in all sectors, branches and sub-sectors of the national economy. Promoting investments in order to solve the problems of upgrading and modernizing the enterprises from different sectors of activity, implementing the achievements of the technical and scientific progress, increasing production and quality, increasing the economic efficiency and the competitive advantage, ensuring a higher level of employment, and so on, demonstrates their important role in ensuring sustainable development in all areas and sectors of activity.

Subsidies are another lever of performance management, which, as we consider, stimulates the sustainable business development in rural areas; subsidies aim to promote economic growth and reduce poverty. Subsidization is an absolutely necessary aid for the sustainable development of agriculture and also a mean of attracting investments in this field. The implementation of the subsidy policy, as well as the on-going review and improvement of the existing subsidy system in agriculture, is in the permanent state's focus. However, we consider it necessary for the state to focus on a series of support measures designed to increase investment in high performing agricultural activities and to limit the phenomenon of unfair competition between producers [6, p.230-231].

The value chain, whose model was first developed by Michel Porter, is another important lever of the performance management. By applying this lever, managers can better understand how added value can be enhanced by a branch, sub-branch or even an enterprise. The correct application and development of the value chain allows the identification of competitive advantage sources, as well as the opportunities for reviewing and designing strategies and activities, both at the enterprise level and at the sector, branch, sub-sector level.

The results provided by the application of this lever significantly contribute to ensuring the competitiveness and sustainable development of a sector, branch, sub-sectors, and enterprise.

The model of the developed value chain is the analysis of the peculiarities between the types of activities within an enterprise. Applying the value chain model, recommended by the author, will allow the identification of sustainable development opportunities for fruit growers. The determination of the value chain developed for certain fruit products has been done in terms of cost, for different clusters, depending on the current market and the potential export markets in the future.

Tables 1-3 present the value chain model developed for the following domestic fruit products: apples, nuts, raspberries.

Table 1

Value chain and added value for apples in the Republic of Moldova

\begin{tabular}{|l|c|c|c|c|c|}
\hline \multirow{2}{*}{\multicolumn{1}{|c|}{ Indicators }} & \multicolumn{5}{c|}{ Markets } \\
\cline { 2 - 6 } & Russia & Romania & Egypt & India & Moldova \\
\hline $\begin{array}{l}\text { Field price (incl. harvesting) excluding } \\
\text { VAT, euro / kg }\end{array}$ & 0,179 & 0,196 & 0,113 & 0,117 & 0,198 \\
\hline Field price including VAT, euro / kg & 0,195 & 0,213 & 0,123 & 0,127 & 0,215 \\
\hline Supermarket entry price, euro / kg & 0,947 & 0,647 & 0,995 & 1,131 & 0,565 \\
\hline Supermarket price (retail), euro/kg & 1,262 & 1,078 & 1,421 & 1,616 & 0,706 \\
\hline
\end{tabular}

Source: Elaborated by the author based on the primary data collected within the research project

"Sustainable development of the horticultural sector in the context of the economic security of the Republic of Moldova", no. 65P, cipher 15.858.06.02A and the sources [13, 14].

Thus, according to Table 1, it was determined that for the domestic apples the traditional export market is the Russian Federation, where the more developed is the storage and sorting infrastructure the more advantageous is the apples price. The major impediment to ensuring the competitiveness of domestic fruit is that the customs regime for the fruit export from the Republic of Moldova provides for the levying of customs duties, which are influenced by the trading period, which substantially increases the Moldovan fruits that become non-competitive on the given market.

At the same time, some alternative markets for diversification of apple trade, e.g. Egypt and India, have been identified, where year-on-year consumption has a fast-growing trend, as they are countries with demographic growth, affordable costs, and fast rhythm of growth. The added value for 
these markets is much more advantageous provided that transport logistics is properly organized (fruits must be able to keep for 60 days: transport and supermarket shelves life) and fruits trading.

The value chain developed for nuts for different clusters, depending on the current market and future export potential, is presented in Table 2.

Table 2

Determination of value chain and added value for nuts from Moldova, euro

\begin{tabular}{|l|c|c|c|}
\hline \multicolumn{1}{|c|}{ Indicators } & \multicolumn{3}{c|}{ Markets } \\
\cline { 2 - 4 } & Middle East & EU & Moldova \\
\hline $\begin{array}{l}\text { Field price (including harvesting cost) excluding VAT, euro } \\
\text { / kg }\end{array}$ & 4,248 & 3,760 & 4,417 \\
\hline Field price including VAT, euro/kg & 4,617 & 4,087 & 4,801 \\
\hline Export price excluding VAT, euro/kg & 5,470 & 4,979 & \\
\hline Supermarket entry price, euro/kg & 6,405 & 5,697 & 6,242 \\
\hline Supermarket price (retail), euro/kg & 10,675 & 11,394 & 8,918 \\
\hline
\end{tabular}

Source: Elaborated by the author based on the primary data collected within the research project "Sustainable development of the horticultural sector in the context of the economic security of the Republic of Moldova", no. 65P, cipher 15.858.06.02A and the sources [13, 14].

Analysing the table data, we can see that nut marketing is much more advantageous and this is explained by increased interest in international markets and walnut kernel deficit. As to the walnuts, the traditional export market is the EU, but they are also steadily exported to the Middle East countries. The EU market will remain a basic customer, but other Asian markets will not be neglected to diversify trade and create added value to nuts marketing.

Table 3 reflects the developed value chain, determined for native raspberries, for different clusters depending on the current market and future export potential.

\section{Determination of the value chain and added value for raspberries from the Republic of Moldova, euro}

\begin{tabular}{|l|l|c|c|}
\hline \multicolumn{1}{|c|}{ Indicators } & \multicolumn{3}{c|}{ Markets } \\
\cline { 2 - 4 } & Russia & EU & Moldova \\
\hline $\begin{array}{l}\text { Field price (including harvesting cost) excluding VAT, } \\
\text { euro / kg }\end{array}$ & 1,226 & 1,188 & 1,024 \\
\hline Field price including VAT, euro/kg & 1,333 & 1,292 & 1,113 \\
\hline Export price excluding VAT, euro/kg & 1,592 & 1,553 & - \\
\hline Supermarket entry price, euro/kg & 2,187 & 1,974 & 1,427 \\
\hline Supermarket price (retail), euro/kg & 3,125 & 3,290 & 1,783 \\
\hline
\end{tabular}

Source: Elaborated by the author based on the primary data collected within the research project "Sustainable development of the horticultural sector in the context of the economic security of the Republic of Moldova", no. 65P, cipher 15.858.06.02A and the sources [13, 14].

Analysing the data of Table 3, we can conclude that the Republic of Moldova has an unexplored potential in the raspberry industry, the intermediaries have to develop and diversify the trade, especially for export, to create opportunities for raspberry producers to develop their production capacities and to modernize technologies. We notice that the strategic markets for raspberries exports will be the EU and the CIS (especially the Russian Federation).

\section{Conclusions}

As a result of the study, we recognize that today's performance management, through its basic features, functions and levers, has become a complex practice that is increasingly difficult to master. But when management is an efficient one, the organization, employees, customers, society, and the country thrive, while poor management makes the same organizations suffer directly or indirectly. Only a management (performance or non-performance) can affect successes or failures for so many people over a long period of time. 
Fruit growers need to understand that an important factor in value chain and added value development is the first segment of the value chain, where the fruit producer is the raw material, which is the most vulnerable segment where the lowest prices are recorded (depending on the field price, which is low in the mass harvesting period and the quality of production is rapidly deteriorating) and it is necessary to facilitate and assist producers to invest and create cold stores individually or through co-operation.

In this context, we recommend to the fruit growers to apply the proposed value chain development model in order to identify and diversify the markets for fruit exports.

\section{REFERENCES}

1. BURDUS, Eugen. Management. Studii de caz, exerciţii, probleme, teste, grile de evaluare. București: Ed. Economica, 2005. 254 p. ISBN 973-709-161-2.

2. BURDUS, Eugen, CAPRARESCU, Gheorghiţă. Fundamentele managementului organizaţiei. Bucureşti: Ed. Economică, 1999. 512 p. ISBN 973-590-209-5.

3. BURLACU, Natalia, COJOCARU, Vadim. Management. Chișinău: Ed. ASEM, 1999. 379 p. ISBN 9975-75-044-3.

4. CUŞNIR, Nicolae. Creşterea competitivităţii întreprinderii prin implementarea managementului performant: (în baza materialelor industriei uşoare din Republica Moldova): teză de doctor. Chişinău: UTM, 2010.135 p.

5. GAVRILA, Tatiana, LEFTER, Viorel. Managementul organizaţional. București: Ed. Economica, 2007. 381 p. ISBN 978-973-709-333-2.

6. LITVIN, Aurelia, DOBROVOLSCHI, Ludmila. Subvenţionarea - ca modalitate de susţinere şi promovare a antreprenoriatului rural în Republica Moldova. Chişinău, 2013. [Accesat 10.11.2018]. Disponibil: http://dspace.uasm.md/bitstream/handle/123456789/550/227231.pdf?sequence $=1 \&$ isAllowed $=y$

7. MANOLESCU, Aurel. Managementul resurselor umane. Ediţia a 4-a. București: Ed. Economica, 2003. 589 p. ISBN 973-590-909-X.

8. MOGA, Toader, RADULESCU, Carmen. Fundamentele managementului. București: Ed. ASE, 2004. 227 p. ISBN 973-594-430-8.

9. NICOLESCU, Ovidiu, VERBONCU, Ion. Fundamentele managementului organizaţional. București, 2008. ISBN 978-973-749-448-1.

10. POPESCU, D. Management. București: Ed. Economica, 2006. 430 p. ISBN (10) 973-709-297-X, ISBN (13) 978-973-709-297-7.

11. URSACHI, Ioan. Management. București: Ed. ASE, 2001. 300 p. ISBN 978-973-709-333-2.

12. MESKON, Majкl, AĹBERT, Majкl, HEDOURI, Franklin. Osnovy menedžmenta. Moskva: Izd-vo Delo, 1997. $488 \mathrm{~s}$.

13. Studiu privind lanţul valoric al sectorului de fructe (mere şi prune) în Republica Moldova. Chişinău, 2009, noiembrie. [Accesat 10.11.2018]. Disponibil: http://agrofarm.md:800/sites/default/files/studiu_lant_valoric_fructe_2009.pdf

14. ZBANCA, Andrei. Problemele noastre reprezintă oportunităţile noastre. Analiza lanţului valoric al strugurilor de masă. [Accesat 10.11.2018]. Disponibil: https://eastfruit.com/storage/conference_materials/pdf/38/5bf3e33bdc3e2.pdf

Recommended for publication: 20.06.2019 
SOCIOLOGY 